\title{
PHILIPPINE BUSINESS CYCLE CHARACTERIZATION A CHRISTIANO-FITZGERALD BAND PASS FILTER REASSESSMENT
}

Gilliane Angela B. De Gorostiza, Ruben Carlo O. Asuncion, and Aekapol Chongvilaivan

NO. 18

August 2019

\section{ADB SOUTHEAST ASIA WORKING PAPER SERIES}


ADB Southeast Asia Working Paper Series

\section{Philippine Business Cycle Characterization: A Christiano-Fitzgerald Band Pass Filter Reassessment}

Gilliane Angela B. De Gorostiza, Ruben Carlo O. Asuncion, and Aekapol Chongvilaivan

No. 18 | August 2019
Gilliane Angela B. De Gorostiza

School of Economics, University of Asia and the Pacific

Ruben Carlo O. Asuncion

Union Bank of the Philippines

Aekapol Chongvilaivan

Southeast Asia Department, Asian Development Bank 
(C) 2019 Asian Development Bank 6 ADB Avenue, Mandaluyong City, 1550 Metro Manila, Philippines

Tel +632632 4444; Fax +6326362444

www.adb.org

Some rights reserved. Published in 2019.

Publication Stock No. WPS190358-2

DOI: http://dx.doi.org/10.22617/WPS190358-2

The views expressed in this publication are those of the authors and do not necessarily reflect the views and policies of the Asian Development Bank (ADB) or its Board of Governors or the governments they represent.

ADB does not guarantee the accuracy of the data included in this publication and accepts no responsibility for any consequence of their use. The mention of specific companies or products of manufacturers does not imply that they are endorsed or recommended by ADB in preference to others of a similar nature that are not mentioned.

By making any designation of or reference to a particular territory or geographic area, or by using the term "country" in this document, $A D B$ does not intend to make any judgments as to the legal or other status of any territory or area.

This work is available under the Creative Commons Attribution 3.0 IGO license (CC BY 3.0 IGO) https://creativecommons.org/licenses/by/3.o/igo/. By using the content of this publication, you agree to be bound by the terms of this license. For attribution, translations, adaptations, and permissions, please read the provisions and terms of use at https://www.adb.org/terms-use\#openaccess.

This CC license does not apply to non-ADB copyright materials in this publication. If the material is attributed to another source, please contact the copyright owner or publisher of that source for permission to reproduce it. ADB cannot be held liable for any claims that arise as a result of your use of the material.

Please contact pubsmarketing@adb.org if you have questions or comments with respect to content, or if you wish to obtain copyright permission for your intended use that does not fall within these terms, or for permission to use the ADB logo.

Corrigenda to ADB publications may be found at http://www.adb.org/publications/corrigenda.

The ADB Southeast Asia Working Paper Series presents data, information, and/or findings from ongoing research and studies to encourage exchange of ideas and elicit comment and feedback about development issues in Asia and the Pacific. Since papers in this series are intended for quick and easy dissemination, the content may or may not be fully edited and may later be modified for final publication. 


\section{CONTENTS}

TABLES AND FIGURES

iv

ABSTRACT

NONTECHNICAL SUMMARY vi vi

$\begin{array}{lr}\text { I. INTRODUCTION } & 1\end{array}$

II. EMPIRICAL METHODOLOGY AND DATA 3

III. STYLIZED CHARACTERISTIC OF THE PHILIPPINE BUSINESS CYCLE 5

A. Volatility 6

B. Co-movement $\quad 7$

C. Persistence $\quad 8$

IV. EMPIRICAL ANALYSIS $\quad 9$

A. Turning-Point Analysis $\quad 9$

V. CONCLUSION AND POLICY IMPLICATIONS 11

REFERENCES 12 


\section{TABLES AND FIGURE}

\section{Tables}

1 Test for Stationarity Using the Augmented Dickey Fuller Test 6

2 Test for Volatility Using Standard Deviation $\quad 7$

3 Test for Co-movement Using Cross-Correlation Matrix $\quad 7$

4 Test for Persistence Using Durbin-Watson d Statistic 8

5 Characteristics of the Real Business Cycle in the Philippines' Turning-Point Analysis 9

\section{Figure}

1 The Philippine Business Cycle, 2003-2017

\section{ABBREVIATIONS}

BSP = Bangko Sentral ng Pilipinas

$C F=$ Christiano-Fitzgerald

$\mathrm{EME}=$ emerging market economies

$\mathrm{CPI}=$ consumer price index

GDP = gross domestic product

LGDP = long-run gross domestic product 


\begin{abstract}
This study presents an assessment of Philippine business cycles through main features (duration, amplitude, and slope) and characterization (volatility, co-movement, and persistence) covering the period 2003-2017. The band pass filter by Christiano and Fitzgerald (2003) is used to decompose the trend cycle and is applied in addition to macroeconomic variables. The Harding and Pagan dating algorithm is additionally employed for robustness check. The period under investigation brought about six cycles: Q4 2002-Q3 2004, Q3 2004-Q4 2006, Q4 2006-Q2 2010, Q2 2010-Q1 2013, Q1 2013-Q1 2015, and Q1 2015-present. Findings from this study show that broad money supply and investment are the most volatile macroeconomic variables while private consumption exhibits the least level of volatility. Inflation also showed low volatility levels, which is attributed to the central bank's inflation-targeting policy. In terms of co-movement, private consumption has the highest co-movement among the observed variables while broad money has the least level of co-movement. Empirical tests also showed that inflation has strong but negative co-movement with gross domestic product. The positive co-movement of government expenditure and broad money with real gross domestic product shows that these fiscal and monetary policy tools are procyclical. Finally, turning-point empirical analysis shows that expansion phases tend to move faster compared to contractions and that the Philippine economy is still in an upturn with output expected to exceed the current trend.
\end{abstract}

Keywords: business cycles, stylized characteristics of business cycles

JEL Classification: E32 E63 


\section{NONTECHNICAL SUMMARY}

This study examines the Philippine business cycle. The Philippine business cycle, just like any other business cycle, can be seen through the path of the real gross domestic product (GDP) since GDP comprises several macroeconomic factors that are substantial in determining real economic activity. After using band pass filter methods to decompose the trend cycle, this study shows that the Philippine economy has already experienced six cycles for the last 14 years: Q4 2002-Q3 2004, Q3 2004-Q4 2006, Q4 2006-Q2 2010, Q2 2010-Q1 2013, Q1 2013-Q1 2015, and Q1 2015-present. This study also reveals that among the macroeconomic factors that determine real GDP, money supply and investments are the most volatile while private consumption is the least volatile. Moreover, since the Philippine economy is driven mostly by domestic consumption or demand, real GDP and private consumption tend to move together. In addition, inflation exhibits negative co-movement with real GDP. Furthermore, this study showed that fiscal and monetary policy tools in the Philippines are procyclical, i.e., the policy stance of the government moves with the movement of the economy. Finally, this study found that expansions in the economy are faster compared to contractions and that the Philippine economy is expected to continue to travel in an upturn. 


\section{INTRODUCTION}

1. The business cycle is the cyclical fluctuation in economic activity that an economy experiences for a certain period. Business cycles vary in duration from more than 1 year to 12 years, and contain a boom (or expansionary phase) and a recession (or contractionary phase) (Leitner 2005). Expansions are characterized by economic growth in real terms, which is evident in the increases in employment, real income, industrial production, and output. Inversely, recessions are characterized by economic contraction, as measured by decreases in the indicators. The expansion is measured from the trough (or bottom) of the previous business cycle to the peak of the current cycle, while a recession is measured from the peak to the trough.

2. The business cycle can be used to effectively position fiscal and monetary policy. If the economy is expecting or is currently experiencing an expansionary phase, then policies should be aimed at maintaining the expansion phase, and at the same time, precluding the economy from overheating. Contrariwise, if the economy is expecting or is currently at a recessionary phase, then policies should be geared toward minimizing the pains of recession and initiate an early economic recovery (Leitner 2005).

3. Consequently, for the past few years, the international economic community has developed a growing interest on documenting stylized features of international business cycles to explain these cycles. The empirical literature on business cycles has rapidly expanded during the last decade: Christodulakis, Dimelis, and Kollintzas (1995) studied the features of business cycles in the Euro Zone countries and found out that there are similarities in the business cycle dynamics across these countries. Backus, Kehoe, and Kydland $(1992,1995)$ examined the stylized characteristics of business cycles in the major industrialized countries. Kose (1999a) examined the cyclical regularities observed in several developing countries in the context of a small open economy Dynamic Stochastic General Equilibrium model and found that the bulk of business cycle fluctuations in aggregate output is explained by world price shocks. Similarly, Aguiar and Gopinath (2007) and (Muñoz 2017) built a Dynamic Stochastic General Equilibrium model with shocks to trend growth to replicate the stylized facts of business cycles in emerging market economies (EMEs). Muñoz (2017) studied the interaction between shortrun business cycle fluctuations and economic growth at the empirical level and was able to identify a measure of potential output with that rate of growth consistent with a constant unemployment rate in 13 Latin American and 18 Organisation for Economic Co-operation and Development member countries.

4. There are also studies focusing on the emerging economies and Asian countries. Hoffmaister and Roldos (1997) studied the sources of macroeconomic fluctuations in Asian economies using a vector autoregressive model and found that the domestic supply shocks account for a significant fraction of the business cycle fluctuations in aggregate output in the Asian countries. Ahmed and Loungani (1998) also examined the sources of macroeconomic fluctuations in Asian economies using a vector-error correction model. Their results suggested that external shocks, foreign output shocks, and oil price shocks play an important role in inducing cyclical fluctuations in output in these countries. Selover (1999) employed bivariate vector autoregressive models and found partial evidence supporting transmission of business cycles among member countries of the Association of Southeast Asian Nations (ASEAN). A study conducted by Calderon and Fuentes (2014) documented the properties of business cycles of 65 countries-22 industrial countries and 43 emerging market economies-using the Harding and Pagan (2002) dating algorithm and found out that recessions are deeper, costlier, and more pronounced; however, recovery for EMEs is swifter and stronger compared to industrialized countries. Duncan (2015) reformulated the model proposed by Aguiar and Gopinath (2007) and employed the simplified model for qualitatively explaining facts such as the highly counter-cyclicality of the trade balance and the higher volatility of output and consumption of EMEs compared with those observed in advanced countries. 
5. Literature in this area of research have primarily focused on business cycle features of major developed economies and a limited number of developing countries. However, only a few studies have examined the stylized features of business cycles of Asian countries, especially the Philippines in which strong growth performance over the last 3 decades has been the subject of intensive research.

6. This study aims to provide a characterization of the Philippine business cycle covering the period 2003 to 2017, following Leitner's (2005) original characterization of the Philippine business cycles from 1981 to 2003. Thus, this study is an update of the domestic business cycle. This study also reports the main features of the Philippine business cycle (duration, amplitude, and slope) and employs the application of the Christiano and Fitzgerald filter on macroeconomic variables apart from gross domestic product (GDP), which is traditionally the case, to be able to identify the stylized characteristics not only on the real business cycle but on these macroeconomic variables as well.

7. This paper is organized as follows: Section II discusses the data and methodology used to extract the business cycle from time series macroeconomic data. Section III discusses the stylized characteristics of business cycles in emerging economies and presents the result for the empirical test conducted. Section $\mathrm{IV}$ provides the findings of the study and conclusion. 


\section{EMPIRICAL METHODOLOGY AND DATA}

8. Business cycles must first be detrended to extract information to be used for its characterization. There are several time-series filters commonly used in macroeconomic and financial research to separate the behavior of a time series into trend, cyclical, and irregular components. In this study, a band pass filter is used to extract valuable information regarding the business cycle trend, which usually has a duration between 5-32 quarters (Christiano and Fitzgerald 2003 and Comin and Gertler 2006). Since the data is that of quarterly growth rates, and since the growth rates of macroeconomic series tend to be nonstationary, the filter also includes a drift in the series (Comin and Gertler 2006).

9. While the literature offers various detrending or smoothing procedures that include first differencing, band pass filters (Baxter and King 1999) and Hodrick-Prescott (HP) filters (Hodrick and Prescott 1997), with the latter being the most frequently applied trend-cycle decomposition technique, these band pass filters have their shortcomings. ${ }^{1}$ The chosen band pass filter for this study - the Christiano and Fitzgerald (CF) filter - can be used to isolate the component of a time series that lies within a band of frequencies and derive approximations that are optimal when the time series representations underlying the raw data have a unit root, or are stationary about a trend (Christiano and Fitzgerald 2003). Although the CF filter can already identify the turning points in the time series data, the Harding and Pagan algorithm, which is a nonparametric approach, will additionally be used as a robustness check to identify the cyclical turning points obtained by the filter.

10. Christiano and Fitzgerald (2003) express a time series $x_{t}$ in terms of frequency $\omega_{i}$, as in the equation below:

$$
\mathrm{x}_{\mathrm{t}}=\mathrm{a}_{0} \sum_{\mathrm{i}=0}^{\mathrm{n}}\left\{\alpha_{\mathrm{i}} \cos \left(\omega_{\mathrm{i}} \mathrm{t}\right)+\beta_{\mathrm{i}} \sin \left(\omega_{\mathrm{i}} \mathrm{t}\right)\right\}+\mathrm{e}_{\mathrm{t}}
$$

11. A specific time series has different frequency components. Let $y_{t}$ denote the data generated by applying the band pass filter $\mathrm{y}_{\mathrm{t}}$ to the raw data $\mathrm{x}_{\mathrm{t}}$ and approximate $\mathrm{y}_{\mathrm{t}}$ by $\hat{\mathrm{y}}_{\mathrm{t}}$ to minimize the mean square error. That is, minimize:

$$
E\left[\left(y_{t}-\hat{y}_{t}\right)^{2} \mid x\right]
$$

12. To isolate the component of $\mathrm{x}_{\mathrm{t}}$ with period of oscillation between $\mathrm{p}_{1}$ and $\mathrm{p}_{\mathrm{u}}, \mathrm{y}_{\mathrm{t}}$, is computed as:

$$
y_{t}=\beta_{0} x_{t}+\beta_{1} x_{t+1}+\cdots+\beta_{T-1} x_{T}+\beta_{T-t} x_{T}+\beta_{1} x_{t-1}+\cdots+\beta_{t=2} x_{2}+\beta_{t-1} x_{1}
$$

For $\mathrm{t}=3,4, \ldots, \mathrm{T}-2$

$$
\begin{gathered}
\beta_{j}=\frac{\left(\sin \left(j_{b}\right)-\sin \left(j_{a}\right)\right.}{\pi_{j}}, j \geq 1 \\
\beta_{o}=\frac{b-a}{\pi}, \quad a=\frac{2 \pi}{p_{u}}, \quad b=\frac{2 \pi}{p_{1}}
\end{gathered}
$$

13. After applying the filter $\mathrm{y}_{\mathrm{t}}$, the components of $\mathrm{x}_{\mathrm{t}}$ with frequency within the lower and upper bounds will be drawn out and the rest of the signals that are out of the range will be offset and excluded by the filter. Since the data are quarterly and $\mathrm{p}_{1}=6$ and $\mathrm{p}_{\mathrm{u}}=32$, then the component of $\mathrm{x}_{\mathrm{t}}$ is with periodicities between 1.5 and 8 years.

1 See Ravn and Uhlig (1997) and Cogley and Nason (1995) for a comprehensive discussion. 
14. To ensure that the long-term trend of the cyclical components is eliminated by the band pass filter, the observed time series data should be tested for stationarity using the augmented Dickey-Fuller unit root test. The augmented Dickey-Fuller performs a test that would determine if a variable follows a unitroot process. The null hypothesis is that the variable contains a unit root, and the alternative is that the variable was generated by a stationary process.

15. The traditional cycle-dating turning-point algorithm by Harding and Pagan (2002) are employed in this study for robustness checks. ${ }^{2}$ The turning-point algorithm searches for local maxima and minima over the series. Besides the basic local maxima and minima searches, this algorithm uses additional censoring rules to identify the cycles. These require specifications on (i) the minimum length of the cycle (the distance between two consecutive peaks or troughs), (ii) minimum length of each phase (contraction from peak to trough or expansion from trough to peak) of the cycle, (iii) peaks and troughs to appear alternately, and (iv) a trough (peak) to be lower (higher) than the preceding peak (trough). Candidate points must then satisfy two conditions: phases are at least "p" quarters long, and complete cycles are at least " $c$ " quarters long-where " $p$ " and " $c$ " are chosen parameters. This study used the default minimum phase length of 2 and the default minimum cycle length of 5 .

16. After the detrending process, the following characteristics can be inferred from the time series data:

- Volatility measures the amplitude and sensitivity to fluctuation of the observed time series data to aggregate fluctuations. It also measures the magnitude of the time series' contribution to aggregate fluctuations. Volatility is measured using the standard deviation wherein a high standard deviation signifies that the variable contributes significantly to aggregate fluctuations. Conversely, a low standard deviation signifies that the variable does not contribute significantly to aggregate fluctuations.

- Co-movements show the correlated or similar movement of the macroeconomic variables to total output. These are measured by the Pearson's correlation coefficient shown in the crosscorrelation matrix wherein positive, negative, or near-zero coefficients point to pro, counter, and acyclical movement, respectively.

- Persistence signifies the inertia in business cycles, particularly the cyclical component, and captures the length of observed fluctuations. Persistence captures the inertia and the length of fluctuations in the business cycle, specifically the cyclical component. Persistence is measured by the first order autocorrelation using the Durbin-Watson statistic, often denoted as $d$.

17. Historical quarterly data on real GDP, Private Consumption, Government Expenditure, Investment, Exports, Imports, Broad Money Supply (M2), Employment, and Inflation are used for characterizing the Philippine business cycles. The historical data covers the period from the first quarter of 2003 until the second quarter of 2017. The data are all obtained from the Philippine Statistical Authority. Output (real GDP) is specifically used to map out the business cycle since it is the best available measure to track economic activity. Real GDP data is seasonally adjusted using a seasonal index.

2 This is more popularly known as BBQ algorithm or Bry and Boschan Quarterly Algorithm. This "BBQ" algorithm was proposed by Harding and Pagan (2002) as a quarterly ("Q") implementation of the original Bry and Boschan (1971) ("BB") monthly algorithm. 


\section{STYLIZED CHARACTERISTIC OF THE PHILIPPINE BUSINESS CYCLE}

18. Emerging market economies (EMEs) like the Philippines are largely characterized by their macroeconomic volatility in a sense that fluctuations in output, exchange rates, and current account balances are normally more recurrent, sharper, and abrupt compared to industrial economies (Calderon and Fuentes 2014). Excess volatility in output fluctuations in EMEs, as compared with industrial countries, has typically been attributed to country-specific factors that amplify external shocks and have led to a higher incidence of banking, currency, and external debt crisis (The World Bank 2007). These factors include EMEs' excessive dependence on few volatile sectors, a narrow tax base, fragile financial systems, weak institutions, and poor economic policies (Calderon and Fuentes 2014).

19. Thus, business cycles in emerging markets are more pronounced than in advanced economies. The average decline in output during recessions is smaller in advanced countries compared to emerging markets, while recoveries in advanced countries are weaker compared to those experienced in emerging markets (Kose, Prasad, and Terrones 2006). However, there is no noticeable difference between advanced and emerging market countries in terms of duration of recessions.

20. Another characteristic of business cycle in emerging economies is the severity of its slope. Recessions in emerging economies are more intense since the slope of recessions in these countries are typically larger and more severe compared to advanced countries. In a similar fashion, recoveries in emerging markets tend to feature a larger slope than those in advanced countries (Kose, Prasad, and Terrones 2006). Moreover, emerging economies have a relatively shorter business cycles and are more volatile on average (Rand and Tarp 2001).

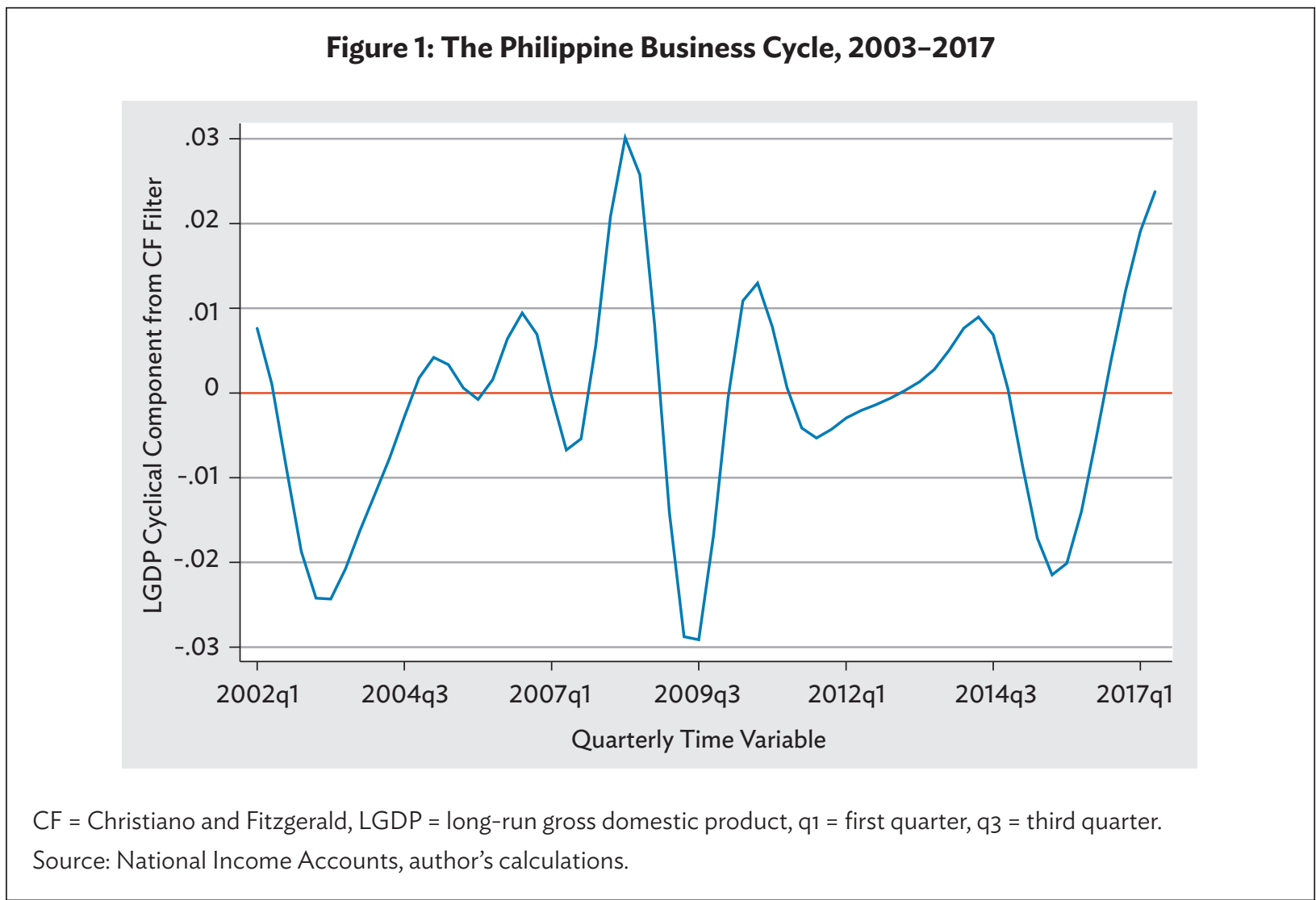


21. Results from the augmented Dickey Fuller Test showed that after detrending, most of the key macroeconomic variables are now stationary and that the long-term trend of the cyclical components is eliminated by the band pass filter. Except for Imports, Broad Money (M2), and Inflation, all time series macroeconomic variables are stationary. Despite being nonstationary, Inflation, M2, and Imports are still included in the characterization of the Philippine business cycles since these variables play a significant role in interpreting real economic activity.

Table 1: Test for Stationarity Using the Augmented Dickey Fuller Test

\begin{tabular}{lccc}
\hline Variable Name & P-value & T-value at 5\% & Test Statistic \\
\hline Real GDP & 0.000 & -3.473 & -5.940 \\
Private consumption & 0.000 & -3.473 & -5.574 \\
Government expenditure & 0.013 & -3.473 & -3.882 \\
Investment & 0.000 & -3.474 & -10.599 \\
Exports & 0.001 & -3.473 & -4.550 \\
Imports & 0.253 & -3.473 & -2.661 \\
M2 & 0.970 & -3.474 & -0.751 \\
Inflation & 0.309 & -3.473 & -2.539 \\
Employment & 0.000 & -3.474 & -5.620 \\
\hline
\end{tabular}

GDP = gross domestic product.

Source: National Income Accounts, author's calculations.

\section{A. Volatility}

22. Table 2 shows the standard deviation for the band pass filtered macroeconomic variables. Among these variables, broad money (M2) and investment are the most volatile component of the business cycle. The high volatility arising from investments can be attributed to the unpredictability of investor confidence. According to Keynes assertion of "animal spirits" of investors, animal spirits are a sort of naive optimism in a sense that it describes the instincts, tendencies, and emotions that presumably influence and guide human behavior, and which can be measured in terms of consumer confidence. Thus, "animal spirits" are believed to be a part of the investment bursts that set off business cycles. M2 also shows high volatility. Bangko Sentral ng Pilipinas (BSP), the central bank of the Philippines, controls money supply through the Open Market Operations to stabilize prices and the economy as a whole. Thus, $M 2$ is volatile since it would have to adjust to market conditions.

23. Since the Philippine economy is domestic consumption-driven, it is no surprise that private consumption is the least volatile variable. In addition, employment and inflation show low volatility. If there is robust economic activity, then employment tends to go up. Consequently, more employed persons result in higher output and productivity, thus, a higher GDP. Surprisingly, inflation is seen to have low volatility. This could be attributed to BSP's inflation-targeting policy. Since the main policy goal of the central bank is to maintain price stability, then inflation would then be relatively stable (compared to broad money). 
Table 2: Test for Volatility Using Standard Deviation

\begin{tabular}{lcc}
\hline Variable Name & \# of Observations & Standard Deviation \\
\hline Real GDP & 78 & 0.058 \\
Private consumption & 78 & 0.009 \\
Government expenditure & 78 & 0.275 \\
Investment & 78 & 2.312 \\
Exports & 78 & 0.211 \\
Imports & 78 & 0.151 \\
M2 & 78 & 2.602 \\
Inflation & 78 & 0.022 \\
Employment & 78 & 0.024 \\
\hline
\end{tabular}

GDP = gross domestic product.

Source: National Income Accounts, author's calculations

\section{B. Co-movement}

24. Table 3 shows the cross correlation of the macroeconomic variables to real GDP. All the variables show significant and positive co-movement with real GDP. All the time series macroeconomic variables are significant at $1 \%$ level except for $M 2$, which is significant at $5 \%$ level, and inflation, which shows high negative co-movement with GDP. The asterisks denote the level of significance; three asterisks show significance at $1 \%$ level, two asterisks show significance at $5 \%$ level, and a single asterisk show significance at $10 \%$ level. Among all the observed variables, private consumption shows the highest co-movement, which is measured using Pearson's correlation coefficient, with real GDP. This shows that the Philippine economy is indeed driven by private consumption. According to the business cycle theory and finance, any economic quantity that is positively correlated with the overall state of the economy is said to be pro-cyclical. ${ }^{3}$ This implies that government expenditure as a fiscal policy tool and M2 as a monetary policy tool are pro-cyclical since they exhibit high co-movement with GDP. It can be inferred that for the observed period, the government did not implement any countercyclical stabilization policy to hasten recovery from economic recessions, which is contrary to what Keynesian economists advocate, that is to use automatic and discretionary countercyclical policies to stimulate the economy when it is in a downturn (or to cool down the economy when it is in an upswing). M2 exhibits least co-movement

Table 3: Test for Co-movement Using Cross-Correlation Matrix

\begin{tabular}{lcc}
\hline Variable Name & Real GDP & Significance Level \\
\hline Private consumption & 0.999 & $0.000^{* * *}$ \\
Government expenditure & 0.963 & $0.000^{* * *}$ \\
Investment & 0.424 & $0.000^{* * *}$ \\
Exports & 0.915 & $0.000^{* * *}$ \\
Imports & 0.924 & $0.000^{* * *}$ \\
M2 & 0.295 & $0.009^{* *}$ \\
CPI & 0.975 & $0.000^{* * *}$ \\
Inflation & -0.524 & $0.000^{* * *}$ \\
Employment & 0.969 & $0.000^{* * *}$ \\
\hline
\end{tabular}

$\begin{aligned} \text { Notes: } & { }^{* *}=\text { significance at } 5 \% \text { level. } \\ & * * *=\text { significance at } 1 \% \text { level. }\end{aligned}$

$\mathrm{CPI}=$ consumer price index, GDP = gross domestic product.

Source: National Income Accounts, author's calculations.

3 See Alesina and Tabellini (2005). 
with GDP since $M 2$ is used by the BSP primarily as a tool to achieve price stability. While inflation shows significant co-movement, it is negatively correlated with GDP. It is generally accepted that inflation has a negative effect on medium and long-term growth. ${ }^{4}$ This is the case since inflation impeded efficient resource allocation by obscuring the signaling role of relative price changes (Fischer 1993).

\section{Persistence}

25. Table 4 shows the persistence of the observed variables as measured by the Durbin-Watson $d$ statistic. The asterisks denote the level of significance-three asterisks show significance at $1 \%$ level, two asterisks show significance at $5 \%$ level, and a single asterisk show significance at $10 \%$ level. With the exception of private consumption, all the observed macroeconomic variables show that there is weak persistence. The presence of serial autocorrelation makes predicting the path of the business cycle difficult.

Table 4: Test for Persistence Using Durbin-Watson d Statistic

\begin{tabular}{lcc}
\hline Variable Name & F & Prob $>$ F \\
\hline Private consumption & 0.743 & 0.392 \\
Government expenditure & 10.830 & $0.002^{*}$ \\
Investment & 330.958 & $0.000^{* * *}$ \\
Exports & 9.179 & $0.003^{* *}$ \\
Imports & 9.954 & $0.002^{* *}$ \\
M2 & 642.856 & $0.000^{* * *}$ \\
Inflation & 333.854 & $0.000^{* * *}$ \\
Employment & 26.129 & $0.000^{* * *}$ \\
\hline
\end{tabular}

Source: National Income Accounts, author's calculations.

4 See Barro (1991), Fischer (1983, 1993), Bruno and Easterly (1998), and Sbordone and Kuttmet (1994). 


\section{EMPIRICAL ANALYSIS}

\section{A. Turning-Point Analysis}

26. After searching the local maximum and minimum points in the individual series by applying the turning-point dating algorithm, a set of peaks and troughs is obtained for each variable. Table 5 captures the features of the business cycles and describe the estimated cycle in terms of amplitude, duration, and slope.

Table 5: Characteristics of the Real Business Cycle in the Philippines' Turning-Point Analysis

\begin{tabular}{lcccccc}
\hline \multirow{2}{*}{ Cycle } & \multicolumn{2}{c}{ Amplitude } & \multicolumn{2}{c}{ Duration } & \multicolumn{2}{c}{ Slope } \\
\cline { 2 - 7 } & Expansion & Contraction & Expansion & Contraction & Expansion & Contraction \\
\hline $2002 q 4-2004 q 3$ & 0.300 & -0.167 & 4 & 3 & 0.075 & -0.056 \\
$2004 q 3-2006 q 4$ & 0.154 & -0.133 & 5 & 4 & 0.031 & -0.033 \\
$2006 q 4-2010 q 2$ & 0.250 & -0.117 & 3 & 5 & 0.083 & -0.022 \\
$2010 q 2-2013 q 1$ & 0.278 & -0.182 & 6 & 7 & 0.046 & -0.026 \\
$2013 q 1-2015 q 1$ & 0.364 & -0.120 & 4 & 4 & 0.091 & -0.030 \\
$2015 q 1-2016 q 1^{\text {a }}$ & 0.242 & -0.067 & 4 & 4 & 0.061 & -0.017 \\
\hline
\end{tabular}

q1 = first quarter, q2 = second quarter, q3 = third quarter, q4 = fourth quarter.

a BB Algorithm declares this period as a half cycle, thus, the last cycle is ongoing.

Source: Author's calculations.

27. The turning-point algorithm shows that among the cycles, Q2 2010-Q12013 has the longest cycle, which lasted for 13 quarters or about 3 years. Incidentally, it is within this period that the two of the episodes on global financial crisis occurred. ${ }^{5}$

28. Amplitude implies the intensity of the variables in each cycle. The amplitude of the expansions during Q1 2013-Q1 2015 has the highest recorded amplitude at 36.36\% while the period Q2 2010-Q1 2013 has the lowest recorded contraction at $-18.82 \%$. It is also interesting to note that the amplitude for contraction during Q4 200-Q2 2010 was least severe compared to other contractions. It could be inferred that the Philippine economy was not severely hit during these episodes in the global financial crisis. The trend in the amplitude of expansions has been increasing since the start of the second cycle. Since the last cycle is currently ongoing, it could be expected that the amplitude of expansion for the last cycle would exceed the previous periods. Moreover, the amplitude for expansion in the current period is most likely to exceed the previous period since the Philippine economy has shown robust performance for the last few quarters and is expected to perform even better with the onset of the current administration's tax reform and infrastructure program. Similarly, the trend of the amplitude for contraction has been decreasing, with an exception for the period Q2 2010-Q1 2013 whose contraction amplitude was a record low among the observations.

29. Duration shows the downturns from peak to trough last. On average, expansions last at about 4.3 quarters while downturns or contractions tend to be a little longer at 4.5 quarters. These findings suggest that contractions in the real business cycle last longer than expansions from trough to peak,

5 The five stages of the most serious crisis to hit the global economy since the Great Depression occurred on the following dates: 9 August 2007, 15 September 2008, 2 April 2009, 9 May 2010, and 5 August 2011. 
thus the business cycle exhibits a skewed distribution. Since the period Q2 2010-Q1 2013 appears to be an outlier, if the period were to be removed, the average expansion and contraction would both be at 4 quarters.

30. The slope of a business expansion or contraction is the ratio of its amplitude to its duration. That is, the slope indicates the "speed" of the movement. The last two columns of Table 5 show that on average, the speed of upturns is at $0.0645 \%$, which is twice as fast as the speed of downturns, which is at $(0.0306) \%$. Thus, expansion phases tend to move faster compared to contractions. 


\section{CONCLUSION AND POLICY IMPLICATIONS}

31. As the literature on business cycles suggests, the Philippine business cycles are more pronounced compared to developed and industrialized countries; the domestic business cycle has a more severe slope and has a shorter cycle duration (Figure 1). In a span of 14 years, the Philippine economy has already experienced six cycles of different lengths and depth. The first cycle occurred from Q4 2002 to Q3 2004 while the last cycle started in the first quarter of 2015 and is still ongoing.

32. The key findings from the characterization of the Philippine business cycle indicate that M2 and investment show the highest volatility among the observed variables while private consumption exhibits the least level of volatility. These results are consistent with Leitner's (2005) findings. However, this study further finds that inflation shows low volatility in the observed period. This could be attributed to the change in the BSP's policy stance of inflation targeting. In terms of co-movement, private consumption has the highest co-movement among the observed variables while $M 2$ has the least level of co-movement. Empirical tests also showed that inflation has strong but negative co-movement with GDP. Moreover, positive co-movement of government expenditure and M2 with real GDP shows procyclical fiscal and monetary tools, respectively.

33. Among the cycles, the highest amplitude was during Q1 2013-Q1 2015 while the longest cycle was during Q2 2010-Q1 2013, which lasted for 13 quarters. Incidentally, it was also during this cycle when the lowest amplitude was recorded. The trend for expansion amplitude is increasing while the trend for contraction amplitude is decreasing during the observed period. The duration of the expansion and contraction do not differ much although the duration of the expansion is a bit longer; thus, the business cycles exhibit a skewed distribution. Empirical tests also show the expansion phases tend to move faster compared to contractions.

34. One policy implication from this empirical exercise is that fiscal policy could offer the impetus for the Philippine economy to sustain high growth; thus, the Philippine government's plan to significantly ramp up public infrastructure investment under the Build, Build, Build Program could give a boost to GDP and sustain the upward trend of the business cycles. The ambitious infrastructure goal will not only spur investment but also sustain strong economic growth. Moreover, underinvestment in the Philippines has long been a major constraint to inclusive growth and sustainable development. Thus, the government's infrastructure program will potentially usher in the "Golden Age of Infrastructure" in the country and push the economy from being domestic consumption-driven to a more investment-driven economy. 


\section{REFERENCES}

Aguiar, M. and G. Gopinath. 2007. Emerging Market Business Cycles: The Cycle is the Trend. Journal of Political Economy. (115). pp. 69-72.

Ahmed, S. and P. Loungani. 1998. Business Cycles in Asia. IMF and Board of Governors of the Federal Reserve System. Manuscript.

Alesina, A. and G. Tabellini. 2005. Why is Fiscal Policy Often Procyclical? Cambridge, MA: National Bureau of Economic Research (NBER).

Asian Development Bank. 2017. Gauging Asia's Business Cycles. Asian Development Outlook (ADO) 2017 Update: Sustaining Development through Public-Private Partnership. Manila. pp. 29-35.

Backus, D. and P. Kehoe. 1992. International Evidence on the Historical Properties of Business Cycles. American Economic Review. 82. pp. 864-888.

Backus, D., P. Kehoe, and F. Kydland. 1992. International Real Business Cycles. Journal of Political Economy. 100. pp. 745-775.

1995. International Business Cycles: Theory and Evidence. In Thomas T. Cooley, ed. Frontiers in Business Cycle Research. Princeton, New Jersey: Princeton University Press.

Barro, R.J. 1991. Economic Growth in a Cross-Section of Countries. The Quarterly Journal of Economics. 106 (2). pp.407-443.

Baxter, M. and R. G. King. 1999. Measuring Business Cycles: Approximate Band-Pass Filters for Economic Time Series. Review of Economics and Statistics. 81 (4). pp.575-593.

Bruno, M. and W. Easterly. 1998. Inflation Crises and Long-Run Growth. Journal of Monetary Economics. 41 (1). pp.3-26.

Bry, G. and C. Boschan. 1971. Cyclical Analysis of Time Series: Selected Procedure and Computer Programs. National Bureau of Economic Research Technical Paper. Cambridge, MA: NBER.

Calderon, C. and R. Fuentes. 2014. Have Business Cycles Changed Over the Last Two Decades? An Empirical Investigation. Journal of Development Economics. 109. pp. 98-123.

Cogley, T. and J. M. Nason. 1995. Effects of the Hodrick-Prescott Filter on Trend and Difference Stationary Time Series Implications for Business Cycle Research. Journal of Economic Dynamics and Control. 19 (1-2). pp. 253-278.

Comin, D. and M. Gertler. 2006. Medium-Term Business Cycles. American Economic Review. 96 (3). pp. 523-551.

Christiano, L. and T. Fitzgerald. 2003. The Band Pass Filter. International Economic Review. 44 (2). pp 435-465.

Christodulakis, N., S. Dimelis, and T. Kollintzas. 1995. Comparisons of Business Cycles in the EC: Idiosyncrasies and Regularities. Economica. 62. pp. 1-27.

Diokno, B. E. 2017. BUILD, BUILD, BUILD to Usher in the Golden Age of Infrastructure. Department of Budget and Management. 25 May. http://www.dbm.gov.ph/?page_id=20383.

Duncan, R. 2015. A Simple Model to Teach Business Cycle Macroeconomics for Emerging Market and Developing Economies. Journal of Economic Education. 46 (4). pp. 394-402.

Fischer, S. 1993. The Role of Macroeconomic Factors in Growth. Journal of Monetary Economics. 32 (3). pp. 485-512.

Harding, D. and A. Pagan. 2002. Dissecting the Cycle: A Methodological Investigation. Journal of Monetary Economics. 49. pp. 365-381.

Hodrick, R.J. and E. C. Prescott. 1997. Post-war U.S. Business Cycles: An Empirical Investigation. Journal of Money, Credit, and Banking. 32 (4). pp.1-16. 
Hoffmaister, A. and J. Roldos. 1997. Are Business Cycles Different in Asia and Latin America? International Monetary Fund Working Paper No: 97/9. Washington, DC: IMF.

Kose, M. A. 2002. Explaining Business Cycles in Small Open Economies: How Much Do World Prices Matter? Journal of International Economics. 56 (2). pp. 299-327.

Kose, M.A., E.S. Prasad, and M.E. Terrones. 2006. How Do Trade and Financial Integration Affect the Relationship between Growth and Volatility? Journal of international Economics. 69 (1). pp.176-202.

Leitner, S. M. 2005. The Business Cycles in the Philippines: A Characterization. Philippine Management Review. 12. pp. 9-22.

Munoz, I. M. 2017. On the Interaction Between Economic Growth and Business Cycles. Macroeconomic Dynamics. 21 (4). pp. 982-1022.

Rand, J. and F. Tarp. 2001. Business Cycles in Developing Countries: Are They Different? Centre for Research in Economic Development and International Trade Research Paper No. 01/21. Nottingham, UK: CREDIT.

Ravn, M.O. and H. Uhlig. 2002. Notes on Adjusting the Hodrick-Prescott Filter for the Frequency of Observations. Review of Economics and Statistics. 84 (2). pp. 371-380.

Sbordone, A. and K. Kuttner. 1994. Does Inflation Reduce Poverty? Journal of Economic Perspectives. 18 (4). pp. 70-72

Selover, D. 1999. International Interdependence and Business Cycle Transmission in ASEAN. Journal of the Japanese and International Economies. 13. pp. 230-253.

World Bank, The. 2007. Country Insurance: Reducing Systemic Vulnerabilities in Latin America and the Caribbean. World Bank Report No. 43066-LAC. Latin America and Caribbean Region: The World Bank. 


\section{Philippine Business Cycle Characterization A Christiano-Fitzgerald Band Pass Filter Reassessment}

This study assesses the Philippine business cycles covering the period 2003 to 2017 through the main features of the Philippine business cycle (duration, amplitude, and slope) and characterization in terms of volatility, co-movement, and persistence. Findings from this study show that broad money supply and investment are the most volatile macroeconomic variables while private consumption exhibits the least level of volatility. Inflation also showed low volatility levels, which is attributed to the central bank's inflation-targeting policy. In terms of co-movement, private consumption has the highest co-movement among the observed variables while broad money has the least level of co-movement. The positive co-movement of government expenditure and broad money with real gross domestic product shows that these fiscal and monetary policy tools are procyclical. Finally, the turning-point empirical analysis shows that expansion phases tend to move faster compared to contractions and that the Philippine economy is still in an upturn with output expected to exceed the current trend.

\section{About the Asian Development Bank}

ADB is committed to achieving a prosperous, inclusive, resilient, and sustainable Asia and the Pacific, while sustaining its efforts to eradicate extreme poverty. Established in 1966, it is owned by 67 members -48 from the region. Its main instruments for helping its developing member countries are policy dialogue, loans, equity investments, guarantees, grants, and technical assistance. 